\title{
Educational Reforms in Morocco: Evolution and Current Status
}

\author{
Vicente Llorent-Bedmar ${ }^{1}$ \\ ${ }^{1}$ University of Seville, Spain \\ Correspondence: Vicente Llorent-Bedmar, Facultad de Ciencias de la Educación. C/Pirotecnia, s/n, 41005 \\ Sevilla, Spain. Tel: 349-5542-0559. E-mail: 1lorent@us.es
}

Received: September 15, 2014 Accepted: October 15, 2014 Online Published: November 26, 2014

doi:10.5539/ies.v7n12p95

URL: http://dx.doi.org/10.5539/ies.v7n12p95

\begin{abstract}
Since 1956, the year in Morocco achieved independence, until now, the school system has been the subject of many discussions and controversies in the most varied areas of the country. We provide data on the educational situation. We analyze the reforms from a critical perspective, ending with final proposals. He underlined that the sector was experiencing a number of difficulties and problems due in particular to the adoption of syllabuses and courses that do not meet the needs of the labour market. Managing human resources is a key component of effective management with significant influence on the overall performance of schools. With a highly centralized structure, is structured in a preschool, primary, school, secondary, vocational and higher education with a very different way called Original Teachings rooted in the principles and ideals of the Arab-Muslim civilization. The latter is structured in three main stages of education: basic, secondary and higher education. We concluded by acknowledging the efforts made in recent years in the Moroccan education sector, although there is still a considerable number of clearly important aspects of improvement.
\end{abstract}

Keywords: Morocco, reform, education, school, system

\section{Introduction}

Since 1956, when Morocco achieved independence, until the present day, the education system has been the subject of endless discussion and controversy in a wide range of national forums. So much so, that from 1956 to 1977, Morocco had some twenty ministers of education (Ibaaquil, 1996), and the changes at the top led to a certain instability and lack of continuity in education policy. The disagreements over the measures to be adopted contrast with the unanimity in their diagnosis of the problems, namely: the uncontrolled growth of students in secondary and higher education, lack of equipment, poor quality, high levels of failure and drop-out rates, deficient teacher training, unsuitable syllabuses, regional imbalances, problems with school attendance for women, lack of coordination with the labor market, and so on.

In the report issued by the World Bank on the situation in Morocco in 1994, it was already considered that education ought to occupy a central position in the reform process that Morocco was due to face at the dawn of the twenty-first century, because: "that is what will ensure the long term establishment of a more efficient economy and a more equitable society" (Banque Mondiale, 1995). The aim of this report was to encourage Morocco to embark on a raft of reforms that would lead to a more modern and competitive economy, enabling the country to play a more active part in the world economy and a competitive role in the international arena as the new century approached. To achieve this, it would have to undertake a thorough reform of its education system, concentrating on improving the quality of its education, the methodologies used and knowledge transmitted, with a view to forming economically active citizens who would be better adjusted socially to a highly competitive system. However, as Morocco was in fact backward and its human resources not adapted to the needs of the labor market, these reforms could not be achieved without "a clearer vision of the kind of future society that Morocco is looking for" (Banque Mondiale, 1995)

Following independence, Mohammed V first of all tackled the educational reforms. Later, his successor, Hassan II, stated emphatically in his Speech from the Throne that: "Our major concern is the reform of the education system" (Hassan II, 1998), and also made numerous changes, prominent among which was the Arabization of the education system.

Since the creation of the Higher Council for Education (CSE), there has been a steady stream of reform projects, in 1975, 1985 and 1995, as well as those resulting from the "Charte Nationale" [National Charter] projects 
introduced in 1978 and 1981. Assessments made by the Special Commission for Education and Training (COSEF) before the latest reform in 1999 concluded that, despite the considerable efforts made, the education system was not fulfilling its role satisfactorily.

In his Speech from the Throne, on March 3, 1999, King Hassan II (Note 1) expressed his decision to set up the COSEF, mentioned above, and charged it with drafting a reform plan for the education system. At the same time, considering that Moroccan society was in a critical situation, handicapped by the evident mismatch between training and employment, and arguing that we live in an age when the progress of nations is intimately linked to scientific knowledge, he concluded by advocating an effective education system that would ensure the sustained development of the country. Days later, the Alaouite king published a royal letter in which he spelt out his decision (Hassan II, 1999, a). The studies of this commission took the form of a document called the "National Charter for Education and Training" (CNEF) (Commission Spéciale Education Formation, 1999), which did not simply confine itself to defining general educational principles, but laid down certain objectives and a calendar specifying the pertinent mechanisms of assessment (Belfkih, 2000), the application of which was scheduled for September 2002.

With the clear intention and need to restructure secondary and technical education, the Ministry of Secondary and Technical Education - responsible for formulating and implementing government policy at this level and for exercising state control over the same level of education in the private sector (Décret $\mathrm{n}^{\circ}$ 2-99-924, 1999) -launched an ambitious process of reform. Its most novel features were the progressive use of new technologies, the implementation of a pedagogical strategy based on the principle that the various sectors involved in education should all play their part, and a grandiose administrative decentralization that gave the Academies more responsibilities.

It was structured in two parts. The first part expressed the fundamental principles - the pillars that the education system was to be based on - as well as its major objectives. The second indicated the priority areas to be reformed, which included the reorganization of the education and training cycles.

The guidelines of this reform had four main themes:

1) Improving the pedagogical quality of secondary education, to be achieved by: revising syllabuses; encouraging pupil self-learning and autonomy; revising school textbooks and the examination system at Baccalaureate level; guaranteeing equality of opportunity for pupils by reducing the number of "paid" supplementary hours (private classes) that pupils take outside their home; and ensuring that pupils receive continual guidance from the earliest years of secondary education to the last.

2) At the organizational level, the terms of reference of the Academies would have increased responsibilities by being supplied with the economic, material and human resources necessary for them to carry out their new tasks. In addition, a framework law would be drafted for secondary and technical schools, a continuous training program established, and administrative and technical staff in the lycées retrained, particularly in information technology and administrative, teaching, school and social affairs.

3) Rationalizing material and financial resources, including making better use of the infrastructure, such as laboratories, sports grounds, school toilet facilities, administrative premises, classrooms, teaching and administrative equipment, audiovisual media, multimedia; proper planning for the use of school books and teaching materials; drafting the budgets related to the deployment of human resources in a more rational way, especially those relating to the mobilization of the teaching staff, their working hours, and so on.

4) Modernizing and coordinating the sector. Foremost in this section is the great importance attached to implementing mechanisms that help to make school life more democratic and encourage more extensive use of information technology in the administrative and financial management of schools, libraries, laboratories, écoles normales supérieures, etc. A National Centre of Technology and Communication was set up to produce teaching and multimedia materials, along with a multidisciplinary educational complex designed to promote the use of new technologies.

With regard to the participation of parents in the school community, we should point out that the CNEF, mentioned earlier, makes direct reference to the parents of pupils, indicating that regional and local councils must give parents and guardians some hope and confidence in their children's future (Commission Speciale Education Formation, 1999, section 15). Parents and guardians should be made aware that education is not solely the responsibility of the school. The family unit, as the main educational institution, should exert a strong influence on the upbringing of children and the success of their schooling, progress in their studies and their subsequent professional life (Commission Speciale Education Formation, 1999, section 16). 
Hassan II's successor, Mohammed VI, stated "The question of education is at the top of our present concerns because of the magnitude of its importance, its impact on the formation of generations, preparing them to take an active role in life, building the nation..." (Hassan II, 1999b). If we add to these declarations that, as in previous years, $25.7 \%$ of the Administration's general budget for 2009 was allocated to the education sector (Institut de Statistique de l'UNESCO, 2011), we shall obtain a fairly accurate idea of the importance given to education by the Moroccan government.

On numerous occasions Mohammed VI has declared that the Moroccan education system is one of his prime concerns. The monarch declared the years 1999-2009 as the "decade of education" and decided to implement the National Charter for Education and Training, containing the guidelines for the present process of educational reform, and whose fundamental objectives are:

- To reduce the illiteracy rate.

- To improve the quality of education.

- To combat inequalities due to economic level and gender.

- To further develop private education.

Given the great power of the king, his involvement in the reforms to the education system, which has always been unwavering, is extremely important. In his speeches, we can trace a consistent political thread running through education:

- "Economic development and the creation of productive employment cannot be achieved without the optimal implementation of the reform of education and training because, despite the measures adopted in this regard, a qualitative reform of training, the eradication of illiteracy, education in values and a search for new financial resources are still needed. We also need to foster the development of the various components of national culture, including support for the Royal Institute of the Amazigh Culture, while guaranteeing the preservation of the Muslim identity in Morocco with its commitment to the unity of the Malachite Rite, and with a complete openness to modernity to construct a society of knowledge and communication" (Speech by His Majesty King Mohammed VI at the opening of the first year of the 7th Parliament, Friday, October 11, 2002).

- "It is important, in the first place, to meet the vital challenge of a thoroughgoing reform of education and training. This is a reform on which our present and our future depend" (Speech by His Majesty King Mohammed VI at the opening of the first year of the 7th Parliament, Friday, October 12, 2007).

- "If we place these sectors of education at the forefront, it is because we wish to be a true barometer for measuring the value, appropriateness and impact of any radical reform. So that the reform of our education system can gather speed and move along the right path, we urge the government to ensure that the reform is properly applied with the Emergency Plan" (...). "Our common objective is to rehabilitate the Moroccan state school in order to restore confidence in this institution, whose aim is to inculcate the values of citizenship in the community and a commitment to establishing the principle of equality of opportunity in the community" (Speech from the Throne, July 30, 2008).

- "The significant reform of the education and training system is the key to the route to be taken to meet the challenges of development, because it must be recognized that this is not only a reform of the sector, but a challenge of greater magnitude. Nevertheless, to meet it, we have no alternative but to promote research and innovation, and to guarantee the improvement of our human resources, our main asset. In this way we shall favor equality of opportunity and help build a knowledge-based society and economy, and at the same time train our young people for productive employment" (Speech from the Throne, July 30, 2009).

It is also of particular interest to know that the Moroccan education system is based on the principles and values of the Islamic faith. Its objective is to shape a virtuous citizen, one who will be a model of integrity, moderation and tolerance, open to science and knowledge, and endowed with a spirit of initiative and creativity. It promotes the time-honored values of faith in Allah, patriotism and a commitment to the constitutional monarchy. It is, at the same time, trying to develop a spirit of dialogue and bring the individual closer to democratic practices without forgetting that education must foster and favor the development of the country, reconciling fidelity to tradition with aspirations to modernity.

In September 1999, the school system in force in Morocco since 1985-86 (Note 2) underwent a new reform as a result of the application of the provisions deriving from the CNEF (1999), the frame of reference for educational reform policy in Morocco. These included:

A. Structural reforms that concentrated on revising the curricula: 
- The traditional five years of primary education plus seven years of secondary education were changed to a basic education of nine years and a secondary education of three years duration (Note 3).

- Basic Education, formerly split into two cycles and followed by a secondary education, was reorganized as follows: a two-cycle primary education, comprising a pre-primary phase of two years and a primary phase of 6 years; a two-cycle secondary education, consisting of a lower middle cycle (three years), referred to as collegial, since it is provided in collèges, and another of qualifying secondary education (three years).

- Qualifying secondary education studies were structured into 5 groups, each one with 3 or 4 sections, giving a total of 17 sections. Thirteen sections of Technical Education were grouped together in a Technology group, in which only 4 basic branches of engineering were not included. An Arts group was created with 3 sections.

- A specific core curriculum was introduced lasting seventeen weeks and valid for both Original Education and General and Technical-Vocational Education.

- Secondary education curricula consisting of compulsory subjects were eliminated and replaced by others with compulsory and optional modules, and based on free choice. These new curricula were characterized by the integration of information technology studies and the incorporation of new subjects, such as: Introduction to Education for Citizenship in primary education and the college; the Amazigh language, to be taught in the first four years of primary education; more French in the second year of primary education; and a second foreign language to be taught in the third year of the collège.

B. The considerable improvement in the quality of the textbooks represents a genuine attempt to break with the past. Textbooks are now based on pedagogical principles, focus on the needs of the students, take into account their intellectual level, so as to encourage development, learning and the acquisition of competences, initiatives and openness to change, as well as to develop democratic attitudes based on human and citizens' rights. To promote these changes, they want to introduce scientific, technological and educational advances as well as foster self-learning and self-assessment.

The diversification of textbooks has replaced the use of the single textbook which had been the norm for some time. Teachers will be able to choose between the different books approved by the authorities. In addition, for the first time in the history of education in Morocco, the design and production of textbooks must respect equity and democratic values, as well as the struggle against violence in all its forms, by showing respect for differences and tolerance. It should be noted that every textbook is accompanied by a staff guide that indirectly contributes to the pedagogic development of the teacher.

C. In order to improve the quality of teaching and education and guarantee equality of opportunity among pupils, exams set at the primary, collège, qualifying secondary and university levels of education were revised. To that end, a more rational use was made of available resources and of the time set aside for the exams in order to increase the prestige of the qualifications, especially the Baccalaureate.

Under this reform, the final evaluation is made up of the arithmetical average of the grades obtained in the national exam (50\%) and the assessment received by the pupil in the course of his studies $(50 \%)$.

D. In order to integrate communication and information technologies into the teaching-learning process, a systemic plan was developed which encompassed pedagogic roles, resources, and training the teaching staff in the specific technical aspects of the new equipment and how to make best use of the new installations. The proposed objective for 2008 was to achieve a ratio of one computer per 40 pupils. (Ministère de l'Éducation Nationale, de l'Enseignement Supérieur de la Formation des Cadres et de la Recherche Scientifique: Aperçu sur le système éducatif marocain. Genève. 8-11 September, 2004). In the same vein, they intend to create an educational television channel to provide support carrying out the educational reform, to mobilize the various participants in education in favour of the desired innovations, and at the same time help strengthen the process of democratization by providing easier access to knowledge.

\section{Morocco's School System}

The Ministry of National Education, Higher Education, Executive Training and Scientific Research is responsible for applying government policy in the realm of education. Its structure is highly centralized. It consists of a large Department for Higher Education, another for School Education, a Standing Committee for Curricula and sixteen Regional Academies of Education and Training (AREFS). These Academies have important powers, the result of the new decentralization policy that Morocco intends to implement. In turn, the Academies are organized into Provincial Delegations of Education that correspond to the administrative divisions of provinces and prefectures. They are responsible for educational affairs, both administratively and pedagogically. 
The system of education and training includes pre-primary, primary, collegial, and secondary education, vocational training and higher education, with a different track called Original Education.

\subsection{Pre-Primary Education}

Pre-primary education is aimed at children between 4 and 6 years of age. Its objective is to facilitate the physical, cognitive and affective development of the child, encouraging autonomy and socialization by developing sensory, motor, imaginative, and expressive skills, among others, and to provide an initiation into basic religious, ethical and civic values; to engage in elementary practical and artistic activities, such as drawing, painting, music and so on; and activities to prepare for reading and writing in Arabic, through a command of spoken Arabic and based on the child's mother tongue.

There are currently various types of pre-primary school in Morocco, and these can be classified as Qur'anic or modern:

\subsubsection{The Two Kinds of Qur'anic School Are (Note 4)}

- The M'sid: these are traditional centers overseen by the Ministry of Religious Affairs, and $12.88 \%$ of pupils are enrolled in them in pre-primary education (El Andaloussi, 2005). The purpose of these schools is wholly religious, and they are widespread in rural areas. They are run by a teacher called a fkih.

- The Kuttâb, or renewed Qur'anic schools: the majority of pupils at this educational level— $77.34 \%$ —attend this kind of school (El Andaloussi, 2005), which is dependent on the Ministry of National Education. Without setting aside their religious ideals or forgetting their origins, they are increasingly coming to resemble kindergartens.

2.1.2. Modern Pre-Primary Education Includes Public Sector, Semi-Public Sector and Private Kindergartens, As Well As Nursery Schools (4-6 Year Olds) Run by the Cultural Services of Countries Such as France or Spain

The private sector caters for a very small number of pupils.

Although it is contemplated in the CNEF, Moroccan pre-school education is neither compulsory nor free. It is estimated that it will be generalized by 2015 , so that it will be necessary to find sites, prepare programs and train qualified staff. These questions are still in their early stages, generating inevitable doubts concerning their implementation.

\subsection{Basic Education}

Basic education is compulsory from 6 to 15 years of age. It begins with Primary Education for pupils of 6 to 12 and is structured in two cycles:

The First Cycle lasts for two years, from 6 to 8 years old. Its main objective is to consolidate and expand on what was learned in the pre-primary stage.

The Intermediate Cycle lasts for four years, from 8 to 12 years of age. Its aim is to develop the children's capabilities, by exploring what was learned at earlier levels in more depth, especially religious, ethical and civic questions; developing their comprehension and expressive skills in Arabic; learning to read, write and express themselves in a first foreign language; and introducing them to the modern technologies of information, communication and interactive creation.

\subsection{Secondary Education}

Secondary education is organized in two independent cycles: compulsory collegial education and qualifying secondary education (post-compulsory). At the end of the three-year Collegial Education, the Brevet d'Enseignement Collégial (BEC) - a certificate enabling progress to the next educational cycle - may be awarded. Qualifying Secondary Education consists of three types of training-general, technical and vocational-with two corresponding types of Baccalaureate: a general one and a technological-vocational one, each with different specialties and a brief period of vocational training.

\subsubsection{Collegial Education Is for Pupils from the Ages of 12 To 15 and Lasts Three Years}

It is open to those young people who have obtained their certificate in primary studies Its aims are: to pursue the general objectives of previous cycles in greater depth; to develop the formal intelligence of the pupil by formulating and solving problems, mathematical exercises and case simulations; to introduce them to the basic concepts and laws of the natural sciences, physical sciences and the environment; to provide a grounding in geography, history and culture; a knowledge of basic human rights and the rights and duties of Moroccan citizens; for students to acquire basic technical, vocational, artistic and sporting skills; to prepare the pupil for continuing his studies or to enter the world of work directly; and, as far as possible, to train the pupil in a particular trade. 
At the end of this type of education, pupils choose either technical secondary education or vocational training, although it must be stressed that, in practice, many of them give up their academic studies to enter the world of work.

At this level there is also the possibility of taking a short course in professional training called a Cycle of Vocational Specialization, which lasts one or two years, depending on the branch selected and the requirements that the student has to fulfill. Its aim is to train qualified employees who can adapt professionally and have the necessary basic skills to enter working life in the various production and service sectors.

\subsubsection{Qualifying Secondary Education (General, Technical or Vocational)}

Students commence these studies when they are fifteen and when they finish depends on the branch chosen; generally, this is at 18 , which implies a three-year course. The aim is to consolidate what was learned in the Collegial School, to enable students to enter the world of work and prepare them for going on to higher education. It is structured in two cycles:

\subsubsection{A Common Core Cycle}

After obtaining the BEC, students who wish to take their studies further must complete this first cycle, which lasts a year. It consists of a set of learning modules whose objectives are: A. to develop competence in reasoning, communication, expression, organization of work and methodical research; B. to develop a capacity for independent learning and flexibility, given the fluctuating demands of working life and innovations in the cultural, scientific, technological and work environments.

\subsubsection{The Present Baccalaureate Lasts Two Years}

Students Who Have Completed the Previous Common Core Cycle Are Admitted to It. It Consists of Two Branches:

- The Baccalaureate in General Education is designed for students to acquire the appropriate level of scientific, literary, economic and social education, one that prepares them for meeting the challenge of higher education with a reasonable guarantee of success. At the end of the course, the General Baccalaureate (BEG) is awarded, which is a prerequisite for admission to the preparatory classes of the Grandes Écoles, university studies and other specialized institutions of higher education.

- Baccalaureate of Technological and Vocational Education. This is aimed at students who have followed the Common Core Cycle or who possess a Vocational Qualification Diploma (DQP). It sets out to provide training for qualified technicians who will carry out middle level functions in firms in any of the various production areas of the economic, social, artistic and cultural sectors. After completing two years, and a month's work experience organized by the firms themselves, the student obtains the qualification of Baccalaureate in Technological and Vocational Education (BETP). This diploma opens the doors to the labor market, to institutions that train skilled technicians, to preparatory classes for the Grandes Écoles and to university study.

The Baccalaureate diploma (BAC) is a qualification awarded to students who pass a series of exams at national level, after they have completed their secondary education.

\subsection{Vocational Training}

The poor opinion that Moroccans have traditionally held—and still do- of vocational and technical education, aimed at the least-favored sectors of society, contrasts with the esteem in which qualifying secondary education is held. This is the education that the children of the wealthy receive. Government authorities are convinced that the path to modernity lies in promoting vocational training with tempting job opportunities, and using this to spearhead reform in the education system. It should however be added that, even at this time, the relationship between effort put into study and income clearly demonstrates that studies and work of an intellectual nature are more profitable

The Royal Speech, delivered on July 8, 1984, by Hassan II (1985), began the process of reforming Vocational Training in Morocco. Its three basic pillars were:

- To reappraise human resources and socioeconomic advancement.

- To improve the quality of education delivered.

- To ensure a better fit between training and employment.

The system of Vocational Training revealed many weaknesses, among which may be cited the inadequate training of the teaching staff, lack of territorial coverage (managing to train only $20 \%$ of the young people who found their first job) and the limited development of Continuous Vocational Training (reaching only $3 \%$ or $4 \%$ of 
declared wage earners) (Ministère de l'Habitat de l'Emploi et de la Formation Professionelle, 1998). Against that background, it was proposed to carry out a reform of Vocational Training, which involved the following changes:

- To increase the number of work placements in firms from 50,000 to $131,000,45 \%$ of which would be for women (Ministère de l'Habitat de l'Emploi et de la Formation Professionelle, 1998).

- Greater autonomy for schools.

- Development of the private sector.

- Greater involvement by firms.

- To improve the prestige of these studies.

The state system of vocational training in Morocco covers the whole country and offers a multiplicity of branches in a variety of fields. There are three levels of training (Agence Marocaine de Coopération Internationale, 2011):

- A Skilled Technician Cycle. After passing the Baccalaureate, students undertake two or three years of extra study.

- A Vocational Qualification Cycle. The qualification is achieved after two years of study. Students who have completed the third (final) year of secondary school may be admitted to it.

- A Specialization Cycle. Students who have successfully completed the fourth year of collegial education may be admitted to this course, which lasts two years. Only foreign students resident in Morocco or Moroccans who do not fulfill the necessary requirements to enter higher education can be admitted to this course.

In 2008, the Minister for Employment and Vocational Training, Jamal Rhmani, presented an emergency plan for the field of vocational training, underpinned by the signing of four important agreements (Ministerè de l'Emploi et de la Formation Professionnelle, July 2008):

- With the Ministry of Agriculture and Fisheries, to set in motion an apprentice training program, aimed at 60,000 young people in the rural areas.

- With the Secretary of State for Traditional Crafts, in order to provide the craft industry with qualified labor, by updating their training and promoting the integration of some 60,000 future craftsmen into the workforce.

- With the Ministry of National and Higher Education, responsible for training and scientific research, to create professional licenses in collaboration with the universities and schools of vocational training.

- With the Ministry of Industry, Commerce and New Technologies, relating to the training of personnel necessary for the comprehensive development of the industrial sector.

\subsection{Higher Education}

After Morocco achieved independence in 1956, the political authorities were faced with the need to train qualified personnel at all levels rapidly. From the outset, the task was basically entrusted to the universities. At the beginning of the 1960s the Moroccan government decided to integrate the economy into the international market. Although it is true that Morocco has gradually increased its presence on the international scene since then until the present day, it is no less true that state-dependent means and structures have not been brought up to date. From this standpoint, if the wholesale reform of the higher education and research system is to be attempted at all, the bases necessary for it must form an integral part of the modernization of the state, particularly the administrative, economic and educational sectors (Hassan II, 1996).

This is a university system cut adrift from its economic and cultural environment, and an obvious sign of this is the huge number of graduates who leave the university and immediately swell the ranks of the unemployed. This problem cannot be attributed exclusively to the labor market failing to absorb enough of these graduates, but rather to the irrelevance of the contents of the degree courses and of the qualifications to the socioeconomic development of the country.

It is true that, since 1978, the authorities have made strenuous efforts to set up new centers of higher education, and in fact, by 1992 the number of such centers had already doubled the number that existed before 1978. Much the same can be said about education expenditure and the evolution of the number of university students, rising from 126,481 in 1984/85 to 242,053 in 1994/95 (Boutalet, 1996).

However, for the Moroccan universities to aspire to greater prestige, the quality of their services had to improve considerably. On the one hand, the role of the state had to change radically, particularly in matters of management and financing; on the other, a suitable basic education, general yet diversified, had to be designed, 
complemented by practical training with technical and professional qualifications, and without losing sight of the needs of the labor market.

As far as Higher Education is concerned, it should be mentioned that the Faculties have been relegated to a secondary position behind the Grandes Écoles, the Écoles Normales Supérieures and the Centres Pédagogiques Régionales. Their limited financial resources were a major contributory factor to their loss of prestige, and led to the erosion of academic standards, leaving the students ill-prepared for professional life, a situation exacerbated by the mismatch between a university education and the needs of the labor market. It has reached such a point that there is a growing feeling of disenchantment and apathy spreading among students when it comes to choosing a degree course. All the sectors involved are convinced that the Moroccan university must reform, in short, adapt and open itself up to its socioeconomic environment.

This duality between university and non-university higher education causes quite a few headaches for secondary school pupils, since the process of career counseling is not ideal for addressing the reality of the situation. The existence of higher education centers which are not particularly selective, as is the case with the universities, and others that are more selective, such as the Grandes Écoles, creates serious difficulties that translate into paradoxical situations when providing guidance.

In the World Bank report mentioned earlier, it was stated that a significant proportion of higher education ought to be in the private sector, and that the state should do its utmost to promote the creation of these private institutions. The problem though is how to restructure the state universities without sufficient motivated, competitive human capital, or essential financial and material resources.

The relatively few university research groups that exist carry out low-level scientific research with limited economic and material means. The staff is sometimes poorly trained, the material resources are precarious and there is, furthermore, a clear mismatch between what is taught and the labor market, all reasons why the Moroccan university has gained a rather poor reputation. A thoroughgoing reform enabling the universities to open up and adapt to their social and economic environment seems to be the only feasible solution.

The initial objective of Moroccanizing Public Administration - which has existed since independence as a means of unifying the population - remains in force; at the same time, they want to improve the quality of education through public investment, although so far the results have not matched expectations. What we actually have is a closed, fossilized, ineffective and unproductive education system, with rampant dissatisfaction among staff and students, offering a higher education which is, in many respects, incompatible with values traditionally associated with universities.

After official declarations about the government's intention to restore the lost prestige of the state university faculties, there is a suspicion that this is just a strategy designed to conceal the devaluation of state education that everyone fears. The policy of privatizing this domain would not have to be to the detriment of state education. Nor should it prevent state centers from being provided with the financial means to enable their students to receive an education that is diversified, effective and autonomous, and in an all-purpose university space which could easily accommodate both state and private universities.

The reform of higher-level studies arises in response to the dysfunctions of today's higher education and research system, and represents a radical change in both its spirit and the way it is run. The reorganization of higher education is the response to four basic objectives:

- Administrative and pedagogical management that is more rational, coherent and effective.

- The university has to take full responsibility for its role as an educator and researcher, in transmitting knowledge and contributing to the economic and social development of the country.

- Implementing a system based on competition, specialization, diversification and regulation.

- Establishing an institutional framework of its own, in which the private sector is taken into account.

The idea is for state, private and non-profit making universities to open up to the modern world and progress, while at the same time preserving the cultural and historical identity of the Moroccans. Their presence must stimulate healthy competition and bring about an improvement in the quality of education delivered by each of them.

This reform process is born of a firm intention to encourage the opening up of the economy and prepare the Moroccan people for the challenges that a highly competitive society is going require them to meet. From the outset, it adopted a realistic attitude when it condemned the irrelevance of education to the real socioeconomic environment of the country, together with the inevitable consequences: unemployment, the difficulties 
experienced by university graduates in finding openings in the labor market, inadequate vocational and professional training, and so on.

If the aim of the reform is to help speed up the incipient development of Moroccan society and its economy, then their human resources and structures for scientific research have to be placed right at the very center. In the first instance, two serious problems have to be faced: A. The huge rise in dropout rates and number of repeat students must be solved to achieve greater cost effectiveness per graduating student. B. The notable increase in graduate unemployment, due to the major distortions existing between the labor market and university education.

Following the reform based on the CNEF - that is, since the 2003/04 academic year-there has been an attempt to adapt Moroccan university education to the system of qualifications in general use in the countries of the European Union, which led to Bachelor Degrees, Masters and Doctorates being awarded. As a result, a system based on modules and semesters was set up. The first intake, which obtained Bachelor degrees at the end of 2006/07, was able to progress to the Master's system ending in 2008.

The first cycle of university education, lasting three years and divided into six semesters, leads to:

- The Diploma in Professional University Education (DEUP), which provides entry to the labor market.

- The Diploma in Basic University Education (DEUF), which is the prerequisite for enrolling on a Master's degree.

Once the DEUF has been obtained it is possible to enroll on a Master's course, which corresponds to the second university cycle. The qualification is awarded after four semesters of study. The Doctorate is the third and final university cycle and the qualification is obtained after successfully defending a doctoral thesis that is estimated to take three or four years to complete. In some centers it is carried out within the framework of the Unit of Training and Research (UFR)

To enter the Grandes Écoles and the Specialized Institutes, it is not only necessary to have passed the Baccalaureate with a good grade, but a specific one year course in the Preparatory Schools and success in the entrance exam are also required.

\subsection{Original Education}

This type of education, inspired in the principles and ideals of Arab-Muslim civilization, which had its golden age in the Middle Ages, deserves a special mention. It is used to transmit knowledge and skills related to subjects such as the Arabic language, philosophy and thought, legislation and Islamic jurisprudence.

Initially, it developed in madrasahs or medersas, generally located close to urban mosques (Note 5), and in zawiyas or zaouias which spread throughout the rural areas and created their own academic space (Note 6). Over time, this kind of education began to be taught in centers of higher learning, such as Qarawyyin University (Note 7), set up in Fez in imitation of other Arab-Islamic universities, such as those in Cairo and Tunis.

Traditionally, the Qur'anic schools (kuttâb o m'sids) (Note 8) were attended by the youngest pupils, who received an Islamic education based on the Qur'an and learnt Arabic through writing and recitation. They learnt to read and write, always in that order. Rote learning, mnemonics and, occasionally, corporal punishment made up the commonest teaching methods and strategies. These schools had essentially religious and social functions and constituted an educational environment in which the individual was socialized.

Both the creation of the Qur'anic schools and instituting the Islamic religion as a compulsory subject helped to strengthen Arabic. Traditionally, the master or fkih of the Qur'anic schools inducted the pupils into knowledge of the Qur'an through reading it and writing, although his work was not restricted to these two aspects; both the content transmitted in class and the discipline of the master served to faithfully reproduce social and family structures. Later, during the French Protectorate, the Administration tried to discredit them, to no avail (Dahir December, 1937). The arrival of independence saw them reinforced, and they were given fresh impetus during 1969/70 when the Alaouite monarch took up a position in favor of the Qur'anic schools (Hassan II, 1969).

Their principal mission was, and still is, to preserve Moroccan identity and maintain the fundamental ethical values and morals of their society. Original education is an aid in reviving and strengthening national identity, making the citizen feel identified with and part of Islamic society.

In 1973, Hassan II gave instructions for a new program called "Basic Skills" to be introduced. This was aimed mainly at restoring the form and content of that kind of education which was in danger of dying out.

In recent years, some aspects of original education have been considerably reformed, by modernizing it to some extent, in order to adapt it to the country's needs. This reform began with a new basic education and the 
introduction of a new system for the Baccalaureate examination, so as to proceed to the adoption of the provisions of the CNEF (Art. 88: 41).

The CNEF lays down that, in original education, there should be schools teaching pre-primary to secondary level, forming gateways to institutions of general education. Similarly, training centers for religious services will be set up (mosque librarians - muecines - masters of the Qur'anic schools in the mosques combating illiteracy, and so on) whose specialties will be determined in accordance with needs. Foreign language teaching and learning will have to be improved and - on the basis of association and cooperation-gateways created and coordination improved between institutions of higher education and other original institutions and universities.

Original education can be divided into three well differentiated levels:

2.6.1 Basic Education, Organizedin Two Cycles

- In the first, which runs for 4 years, the pupils learn the Qur'an. No age limit is specified, although the norm is to finish it by the age of 12 .

- The second cycle lasts for 3 years. Admission is open to pupils who have successfully completed the first cycle of original education and to those coming from general basic education.

\subsubsection{Secondary Education}

This cycle is followed by those pupils who have successfully completed the second cycle of original education or pupils from the second cycle of general education (Note Ministerielle, 1992). These centers cater for pupils who wish to pursue their higher education in faculties specializing in Qur'anic studies. The academic timetable varies between 27 and 42 hours per week.

The course lasts three years and is organized in three branches:

- Sharia (Islamic Law).

- Arts (Language, History, Geography etc).

- Experimental Sciences.

\subsubsection{Higher Education}

Studies take place in the Faculties of the University Al Qarawyyin and Darolhadital-Hassania, in other Arts and Law Universities, and in certain institutions of higher education. This educational level is reserved exclusively for those in possession of the Baccalaureate in Original Education.

\section{References}

Agence Marocaine de Coopération Internationale. (2011). Formation au Maroc/Formation. AMCI professionnelle. Retrieved from http://www.amci.ma/formationProfessionnelle.asp? $\mathrm{r}=51 \& \mathrm{sr}=57$

Banque Mondiale. (1995). Rapport de la Banque Mondiale de 1994: dépense publique au Maroc. Rabat: Banque Mondiale.

Belfkih, M. (2000). Appearing in the program Hadith Al-Arbiâ. Broadcast on the $2 \mathrm{~N}$ television channel, Wednesday October 4.

Boutalet, H. (1996). Réflexions sur l'Enseignement Supérieur et la Recherche Scientifique au Maroc. Casablanca: Éditions Maghrébines.

Commission Spéciale Éducation Formation, Royaume du Maroc. (1999). Charte Nationale d'Éducation et de Formation. Royaume du Maroc. Retrieved from http://www.uh2c.ac.ma/uh2c/loi/charte_fr.pdf

Dahir. (1937). Royaume du Maroc, 11 Decembre.

Décret $n^{0}$ 2-99-924. (1999). Décret du chaabane 1.420 (3 decembre) fixant les attributions du Ministère de l'Enseignement Secondaire et Technique. Royaume du Maroc.

El Andaloussi, K. (2005). 50 ans de développement humain au Maroc et perspectives pour 2025. Retrieved from http://www.rdh50.ma/fr/pdf/contributions/GT4-1.indd.pdf

Hassan II. (1969). Speech of October 9.

Hassan II. (1985). Restated in the later Royal Speech, in July.

Hassan II. (1996). The Speech from the Throne delivered by HM King Hassan II, March 3.

Hassan II. (1998). Speech from the Throne delivered by HM King Hassan II, March 3. 
Hassan II. (1999a). Royal Letter of Hassan II concerning the methodology and objectives of the reform project for the teaching and education system (Monday March 8, 1999).

Hassan II. (1999b). Speech from the Throne delivered by HM King Hassan II, Friday July 30.

Ibaaquil, L. (1996). L'école marocaine et de la compétition sociale. Stratégies. Rabat: Edition Babil.

Institut de Statistique de L’Unesc. (2011). Profil éducation. Tous les niveaux. Maroc. Retrieved from http://stats.uis.unesco.org/unesco/TableViewer/document.aspx?ReportId=121\&IF_Language=fra\&BR_Cou ntry $=5040 \& B R \_$Region $=40525$

Ministère de l'éducation Nationale, de l'enseignement Supérieur de la Formation des Cadres et de la Recherche Scientifique. (2004). Royaume du Maroc: Aperçu sur le systeme educatif marocain. Retrieved from http://www.ibe.unesco.org/International/ICE47/English/Natreps/reports/morocco.pdf

Ministerè de l'emploi et de la Formation Professionnelle. (2008). Signature de quatre conventions pour l'activation $d u$ plan d'urgence présenté par Monsieur le Ministre. Retrieved from http://www.emploi.gov.ma/affdetail.asp? codelangue $=23 \&$ info $=1358$

Ministère de l'habitat de l'emploi et de la Formation Professionelle. (1998). Projet de Réforme du Système d'Éducation et de Formation. Rabat: Departement de la Formation Professionnelle.

Note Ministerielle. (1992). Royaume du Maroc, núm. 91, May 31.

\section{Notes}

Note 1. Reform is nothing new. Hassan II himself had already declared in his Speech from the Throne in 1996: "the reform we refer to ... is not confined to reviewing certain provisions laid down in the Constitution. This is a comprehensive reform which involves the Administration, Economy and Teaching sectors".

Note 2. The development strategies for basic and secondary education, implemented from 1985 onwards, had the clear objective of making basic education available to all and of improving the quality of education in all cycles and at all levels by instituting various kinds of structural, pedagogical and organizational measures.

Note 3. Earlier, in June 1987, a process of reforming high school education began, which involved three changes of great importance for the Baccalaureate examinations, known as the BAC. We are referring to the creation of the regional Academies, the establishment of new branches in secondary education and the introduction of a new evaluation system.

Note 4. Also known generically as kuttâb.

Note 5. The medersas were spaces devoted to the study of the Qur'an. In imitation of the Orient, they were established in Morocco from the thirteenth century, were confined to the large cities and acquired a more theological nature than the zaouïas.

Note 6. The Almoravids (1060-1147) and the Almohads (1147-1248) set up the zaouïas, educational centers appointed to teach religion and a certain warlike proselytism.

Note 7. It originated in the year 859 (245 in Islamic chronology), when Fátima Al Fihriya established an educational center attached to the mosque of the same name, which evolved until it became a university.

Note 8. The Qur'anic schools, known as kuttâb in the Arab-Islamic world and m'sid in various regions of Morocco, had a predominantly religious and social purpose.

\section{Copyrights}

Copyright for this article is retained by the author(s), with first publication rights granted to the journal.

This is an open-access article distributed under the terms and conditions of the Creative Commons Attribution license (http://creativecommons.org/licenses/by/3.0/). 